\title{
アブシジン酸誘導気孔閉口におけるカルシウムシグナル制御機構 明らかになった植物のカルシウムシグナル暗号解読システム
}

カルシウムイオン $\left(\mathrm{Ca}^{2+}\right)$ は，ほぼすべての真核生 物において重要なセカンドメッセンジャーとして機能す る。植物において $\mathrm{Ca}^{2+}$ は, 非生物学的ストレス応答 (塩・乾燥など), 病害応答, ミネラル吸収, 光感知など 数多くの重要な生理学的過程の調節に関与することが知 られている(図1)。さまざまな環境刺激は，細胞質遊 離 $\mathrm{Ca}^{2+}$ 濃度 $\left(\left[\mathrm{Ca}^{2+}\right]_{\mathrm{cyt}}\right)$ の上昇を誘導する。 $\left[\mathrm{Ca}^{2+}\right]_{\mathrm{cyt}}$ 上昇は, カルモジュリンや $\mathrm{Ca}^{2+}$ 依存性タンパク質リン 酸化酵素 $\left(\mathrm{Ca}^{2+}\right.$-dependent protein kinase; $\left.\mathrm{CPK}\right)$ など の $\mathrm{Ca}^{2+}$ センサータンパク質によって認識され，下流の シグナル伝達を活性化する。モデル植物であるシロイヌ ナズナのゲノム上には， $\mathrm{EF}$ ハンド $\left(\mathrm{Ca}^{2+}\right.$ 結合モチー フ）を有する $\mathrm{Ca}^{2+}$ センサータンパク質をコードする遺 伝子が 200 個以上存在することが示されており ${ }^{(1)}$, 多く の細胞で複数の $\mathrm{Ca}^{2+}$ センサータンパク質が同時発現し ていることが明らかとなっている。ここで起こる疑問 は, 数多くのシグナル伝達で働く共通メッセージである $\mathrm{Ca}^{2+}$ を, 植物はどのように解読して入力刺激を判別し, 適切な生理応答へと導くのか, という点である（図1). 植物に㧍けるこの $\mathrm{Ca}^{2+}$ シグナル暗号解読機構の一端が 近年明らかとなった。

陸生高等植物の葉の表皮に存在する気孔は，一対の孔 辺細胞と呼ばれる細胞から形成された小孔である．植物 は気孔を開くことで，光合成に必要な二酸化炭素を吸収 し，また同時に蒸散により水蒸気を放出することで土壤

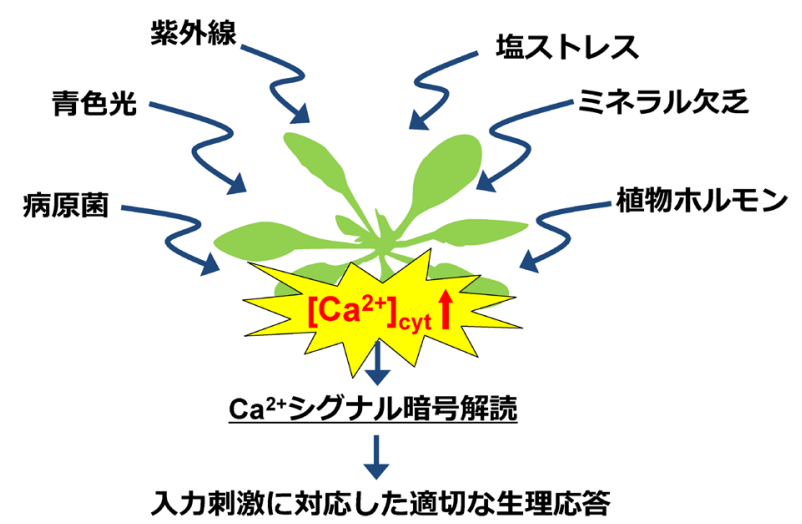

図 1 - $\mathrm{Ca}^{2+}$ はさまざまな生理応答を制御するセカンドメッセン ジャーである
中の栄養を根から吸収するために必要な駆動力を得てい る. しかし水の利用が限られた乾燥ストレス下では, 植 物は気孔を速やかに閉口し水分損失を抑制する必要があ る。この乾燥ストレスに応答した気孔閉口を制御する植 物ホルモンがアブシジン酸（ABA）である，ABAは乾 燥ストレス下で生合成され，気孔閉口を誘導することで 過度の蒸散による水分損失を抑制する，気孔閉口運動を 制御する孔辺細胞 $\mathrm{ABA}$ シグナル伝達に抢いて, $\mathrm{Ca}^{2+}$ は 重要なセカンドメッセンジャーとして機能することが 20 年以上も前から明らかとなっている(2). ABA に応答 して速やかに孔辺細胞 $\left[\mathrm{Ca}^{2+}\right]_{\mathrm{cyt}}$ の上昇が起こる. $\left[\mathrm{Ca}^{2+}\right]_{\mathrm{cyt}}$ 上昇によって, $\mathrm{Ca}^{2+}$ センサータンパク質 $\mathrm{CPK}$ が活性化する。活性化した CPKは，孔辺細胞原形質膜 に存在する陰イオン排出チャネルSLAC1をリン酸化す る.リン酸化されたSLAC1は孔辺細胞から陰イオンの 排出を誘導する，その結果，原形質膜が脱分極し電位依 存性カリウムイオンチャネル GORKによるカリウムイ オンの流出, 浸透圧の低下に伴う水の流出が起こり, 膨 圧が低下し最終的に気孔が閉口する（図2）。

過去の多くの研究によって, 孔辺細胞 $\left[\mathrm{Ca}^{2+}\right]_{\mathrm{cyt}}$ 上昇 は，ABA 処理せずとも一定の割合で観察されることが 報告されている。また興味深いことに $\mathrm{Ca}^{2+}$ は，気孔開 口を誘導する青色光のシグナル伝達においても正の調節 因子として機能することが示唆されている(3)．気孔の開 口と閉口，その両方の調節に関与するメッセンジャー

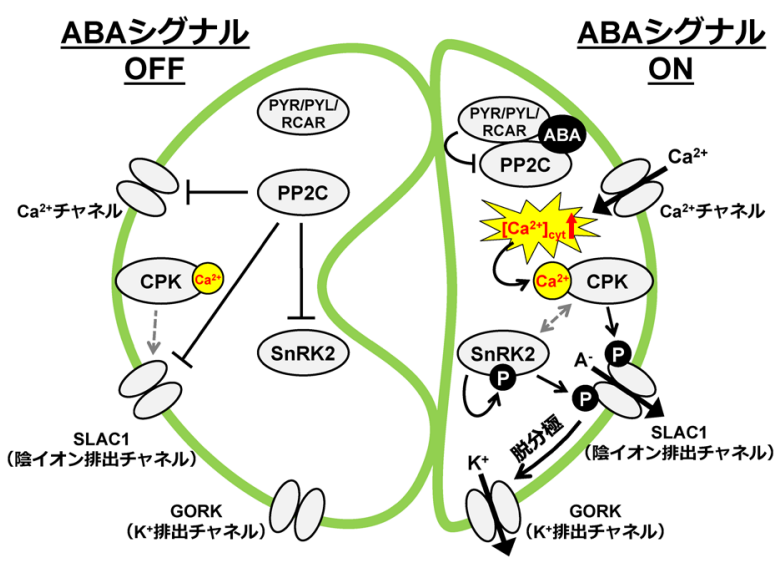

図 2 ■ 孔辺細胞における ABA シグナル伝達の模式図 
$\mathrm{Ca}^{2+}$ ，いったい孔辺細胞はこの $\mathrm{Ca}^{2+}$ 暗号をどのように 解読しているのだろうか?

米国カリフォルニア大学サンディエゴ校Julian Schroeder博士らの研究グループは, ABA シグナル伝達の負 の制御因子であるタンパク質脱リン酸化酵素 $2 \mathrm{C}$ ( $\mathrm{PP} 2 \mathrm{C}$ ) を機能欠損したシロイヌナズナ変異体が, 非特異的な孔 辺細胞 $\left[\mathrm{Ca}^{2+}\right]_{\mathrm{cyt}}$ 上昇に応答することを見いだした(4). 野生株では, 孔辺細胞 $\left[\mathrm{Ca}^{2+}\right]_{\mathrm{cyt}}$ 上昇を人為的に誘導し ても，ABAが存在しなければSLAC1チャネルの活性化 は起こらない。ところが $\mathrm{PP} 2 \mathrm{C}$ 遺伝子破壊変異体では, $\mathrm{ABA}$ が存在せずとも， $\left[\mathrm{Ca}^{2+}\right]_{\mathrm{cyt}}$ 上昇に応答して SLAC1 チャネル活性化が起こる(4).

$\mathrm{ABA}$ シグナルの初期応答は, $\mathrm{ABA}$ 受容体である PYR/PYL/RCAR, PP2C, そして Ca ${ }^{2+}$ 非依存性タンパ ク質リン酸化酥素SnRK2によって制御される（図2). ABA 非存在下では，PP2CがSnRK2を脱リン酸化する ことで下流のシグナル伝達を抑制している. SnRK2は, $\mathrm{CPK}$ と同様にSLAC1をリン酸化して活性化することが 報告されている，最近の研究によって，PP2CがSnRK2 に加えて, SnRK2 と CPKの基質である $\mathrm{SLAC1}$ を直接脱 リン酸化することが明らかとなった(4,5).

以上の研究成果をまとめると(6), ABA シグナルが $\lceil\mathrm{OFF} 」$ の状態一すなわち, PP2CがSLAC1を脱リン酸 化している状態—では, $\left[\mathrm{Ca}^{2+}\right]_{\mathrm{cyt}}$ 上昇によって CPKが 活性化しSLAC1をリン酸化しても, PP2Cが速やかに SLAC1を脱リン酸化する (図 2 : 左側)。そのためSLAC1 は活性化せず，気孔は閉口しない。つまり非特異的 $\left[\mathrm{Ca}^{2+}\right]_{\mathrm{cyt}}$ 上昇によるSLAC1活性化，それに続く気孔閉 口応答を $\mathrm{PP} 2 \mathrm{C}$ が抑制しているのである。 反対に $\mathrm{ABA}$ シグナルが「ON」の状態一すなわち, ABAが受容体 PYR/PYL/RCARによって認識されてPP2Cが不活性化 している状態—では, SnRK2 とCPKによってリン酸化 されたSLAC1が活性化し, 気孔が閉口する（図2：右 (側). 以上の研究成果は, PP2Cによる $\mathrm{SLAC1}$ の脱リン 酸化が, 孔辺細胞 $\mathrm{Ca}^{2+}$ シグナルの特異性を決定する キーステップであることを示すものである.

\section{今日の話題}

SnRK2が媒介する $\mathrm{Ca}^{2+}$ 非依存性経路と CPKが媒介す る $\mathrm{Ca}^{2+}$ 依存性経路に何らかのクロストーク機構が存在 することが示唆されている(蚆 2 (右側)。しかしその 詳細は不明である。またアフリカッメガエル卵母細胞を 用いた異種発現系での解析によって, CPKとは別夕イ プの $\mathrm{Ca}^{2+}$ 感受性タンパク質リン酸化酵素による SLAC1 活性制御機構の存在も示唆されているが, 植物体を用い た解析はまだ行われておらずその生理学的意義は不明で ある(5). 今後の研究により植物に扔ける $\mathrm{Ca}^{2+}$ シグナル の理解が進むことが期待される.

1) I. S. Day, V. S. Reddy, G. Shad Ali \& A. S. Reddy: Genome Biol., 3, research0056.1 (2002).

2) M. R. McAinsh, C. Brownlee \& A. M. Hetherington: Nature, 343, 186 (1990).

3) K. Shimazaki, M. Doi, S. M. Assmann \& T. Kinoshita: Annu. Rev. Plant Biol., 58, 219 (2007).

4) B. Brandt, S. Munemasa, C. Wang, D. Nguyen, T. Yong, G. P. Yang, E. Poretsky, F. T. Belknap, R. Waadt, F. Aleman et al.: eLife, 4, e03599 (2015).

5) T. Maierhofer, M. Diekmann, J. N. Offenborn, C. Lind, H. Bauer, K. Hashimoto, K. A. S. Al-Rasheid, S. Luan, J. Kudla, D. Geiger et al:: Sci. Signal., 7, ra86 (2014).

6) S. Munemasa, F. Hauser, J. Park, R. Waadt, B. Brandt \& J. I. Schroeder: Curr. Opin. Plant Biol., 28, 154 (2015).

(宗正晋太郎, 岡山大学大学院環境生命科学研究科)

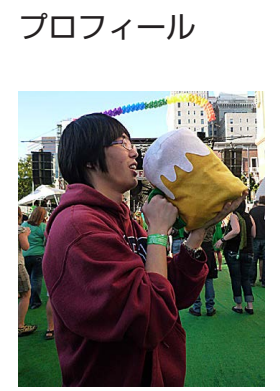

宗正 晋太郎 (Shintaro MUNEMASA) $<$ 略歴 $>2004$ 年岡山大学農学部総合農業 科学科卒業 $/ 2009$ 年同大学大学院自然科 学研究科博士後期課程修了 / 同年日本学術 振興会特別研究員 PD (DCからの資格変 更) / 2010 年カリフォルニア大学サンディ エゴ校博士研究員 $/ 2012$ 年日本学術振興 会海外特別研究員 /同年岡山大学大学院環 境生命科学研究科助教, 現在に至る<研究 テーマと抱負>植物のイオンチャネル活性 制御機構・カルシウムシグナル伝達機構の 解明<趣味>モータースポーツ観戦, 麻 雀, ポケモン対戦. 釣りとテニスも始めた いです

Copyright (C) 2017 公益社団法人日本農芸化学会 DOI: 10.1271/kagakutoseibutsu.55.666 